\title{
Rearing two fruit flies pests on artificial diet with variable $\mathrm{pH}$
}

\author{
N. P. Dias ${ }^{a}$, D. E. Nava ${ }^{b}$, G. Smaniotto, M. S. Garcia ${ }^{a}$ and R. A. Valgas ${ }^{b}$ \\ ${ }^{a}$ Departamento de Fitossanidade, Universidade Federal de Pelotas - UFPel, Campus Universitário, \\ Avenida Eliseu Maciel, s/n, CEP 96010-900, Pelotas, RS, Brasil

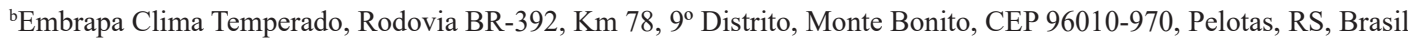 \\ 'Instituto de Biologia, Universidade Federal de Pelotas - UFPel, Campus Universitário, \\ Avenida Eliseu Maciel, s/n, CEP 96010-900, Pelotas, RS, Brasil \\ *e-mail: nayma.dias@gmail.com
}

Received: May 2, 2017 - Accepted: September 19, 2017 - Distributed: February 28, 2019

\begin{abstract}
Fruit flies (Diptera: Tephritidae) are considered the main fruit pests worldwide. In Brazil, two species are predominant: the South American fruit fly, Anastrepha fraterculus and the Mediterranean fruit fly, Ceratitis capitata. In this study, we evaluated the effect of artificial diets with variable $\mathrm{pH}$ in their larval development and adult performance. The experiments were carried out in the laboratory at $25 \pm 2{ }^{\circ} \mathrm{C}, 70 \pm 10 \% \mathrm{RH}$ and 12:12h (L:D) photoperiod. Semisolid diets with $\mathrm{pH}$ values of $6.0,5.0,4.0,3.0,2.0,1.5$, and 1.0, adjusted by adding hydrochloric acid were tested. Results indicated that the diet with $\mathrm{pH} 6.0$ did not support larval development of both species of fruit fly. Diets with greater acidic $\mathrm{pH}$ values did not allow egg, larvae or pupae development and adult reproduction of $A$. fraterculus. For C. capitata, the $\mathrm{pH}$ of artificial diet exerts greater influence compared to A. fraterculus on the duration and viability of the larval stage, number of pupae, sex ratio and longevity of males.
\end{abstract}

Keywords: Anastrepha fraterculus, Ceratitis capitata, biological parameters, aciddific agent.

\section{Criação de duas moscas-das-frutas praga em dieta artificial com variação de pH}

\begin{abstract}
Resumo
As moscas-das-frutas (Diptera: Tephritidae) são consideradas as principais pragas da fruticultura mundial. No Brasil, duas espécies são predomindantes: a mosca-das-frutas Sul-americana, Anastrepha fraterculus e a mosca-do-Mediterrâneo, Ceratitis capitata. Neste estudo avaliamos o efeito de dietas artificiais com $\mathrm{pH}$ variável no seu desenvolvimento larval e performance de adultos. Os experimentos foram realizados em laboratório a $25 \pm 2{ }^{\circ} \mathrm{C}, 70 \pm 10 \%$ UR e fotoperíodo de 12:12 horas. Foram testadas dietas semi-sólidas com valores de pH de 6,0; 5,0;4,0;3,0;2,0; 1,5 e 1,0, ajustados pela adição de ácido clorídrico. Os resultados indicaram que a dieta com pH 6,0 não suportou o desenvolvimento larval de ambas as espécies de mosca-das-frutas. As dietas com $\mathrm{pH}$ ácido não permitiram o desenvolvimento de ovos, larvas ou pupas e a reprodução de adultos de A. fraterculus. Para C. capitata o $\mathrm{pH}$ da dieta artificial exerceu maior influência do que para $A$. fraterculus nos parâmetros de duração e viabilidade do estágio larval, número de pupas, razão sexual e longevidade de machos.
\end{abstract}

Palavras-chave: Anastrepha fraterculus, Ceratitis capitata, parâmetros biológicos, agente acidificante.

\section{Introduction}

Fruit flies (Diptera: Tephritidae) are considered the main fruit pests worldwide (Ruiz et al., 2014). In Brazil, two species are predominant: the South American fruit fly, Anastrepha fraterculus (Wiedemann, 1830), infesting 114 species and the Mediterranean fruit fly, Ceratitis capitata (Wiedemann, 1824), with 93 reported hosts (Zucchi, 2008, 2012).

Host selection by Tephritidae is determined for several factors including the chemical properties of the fruit (Papachristos and Papadopoulos, 2009). The concentration of hydrogen ions $\left(\mathrm{H}^{+}\right)$, or $\mathrm{pH}$, is vital to ensure biological process that affect physiology, survival and symbiosis
(DiMario and Mahowald, 1986; Koval and Suppes, 1990). In general, insects regulate $\mathrm{pH}$ to support acidic environments and intestinal $\mathrm{pH}$ changes, caused by the type of food infested (Harrison, 2001).

For fruit flies, the host fruit $\mathrm{pH}$ is considered a limiting factor, as reported in guava fruits (Psidium guajava L.) for A. fraterculus (Oliveira et al., 2014) and citrus (Citrus spp.) for $C$. capitata (Papachristos et al., 2008). However, despite its importance, few studies have discussed the influence of $\mathrm{pH}$ in artificial diet on the biology of Tephritidae (Vargas et al., 1984; Chan Junior and Jang, 1995; Hu et al., 1999; Vera et al., 2014). 
Artificial diets for rearing and maintaining insects in the laboratory have applications in basic and applied research (Parra, 2009). The knowledge of the target species biology is crucial for the success of mass rearing (Cladera et al., 2014). Any change in the diet quality during immature development can have a significant effect on their biological characteristics (Chapman, 2013; Nestel et al., 2016).

The $\mathrm{pH}$ influences the palatability and stability of the diet, the activity of preservatives, the solubility of nutrients and probably many other not yet determined factors (Cohen, 2004). In addition, the $\mathrm{pH}$ currently used for rearing from fruit flies (4.5), may result in microbial growth and early deterioration of the diet (Vera et al., 2014). Therefore, we evaluated artificial diets with different $\mathrm{pH}$ values for egg, larvae and pupae development of $A$. fraterculus and C. capitata.

\section{Material and Methods}

The study was conducted at the Entomology Laboratory of Brazilian Agricultural Research Corporation (EMBRAPA) (Pelotas, Rio Grande do Sul, Brazil), in a rooms kept at $25 \pm 2{ }^{\circ} \mathrm{C}, 70 \pm 10 \% \mathrm{RH}$ and $12: 12 \mathrm{~h}$ (L:D) photoperiod. The adults of $A$. fraterculus and $C$. capitata used in the experiment were obtained at the Food Irradiation and Radioentomology Laboratory of CENA/USP (Piracicaba, São Paulo, Brazil).

\subsection{Fruit flies rearing}

Adults of $A$. fraterculus were kept in plastic cages $(57 \times 39 \times 37 \mathrm{~cm})$. Water and solid diet, composed of refined sugar, wheat germ, and yeast at a ratio of 3:1:1 were offered (Nunes et al., 2013). Eggs were collected from screens placed on the cage sides and were transferred to Erlenmeyer-type glass containers $(500 \mathrm{~mL})$, where they remained for a $24 \mathrm{~h}$ aeration process. For the rearing of $C$. capitata, adults were kept in plastic cages $(48 \times 30 \times 30 \mathrm{~cm})$ containing water and same solid diet as described. The methodologies used for collecting eggs and for the aeration and inoculation processes were based on Gonçalves et al. (2013).

\subsection{Diets preparation}

The semisolid diets were prepared according to the methodology described by Salles (1992) and Nunes et al. (2013). For the diets preparation, the following components were homogenised in blender: refined sugar, lyophilized brewer's yeast Brewcell (Biorigin, Lençóis Paulista, SP), cread wheat germ (Walmon, São Paulo, SP) and distilled water. The components, methylparahydroxybenzoate Nipagin $^{\mathrm{TM}}$ (Vetec, Química Fina Ltda., Duque de Caxias, RJ) (diluted to $10 \%$ in ethyl alcohol), sodium benzoate (Vetec) (dissolved in $20 \mathrm{~mL}$ of distilled water) and hydrochloric acid (Synth, Diadema, SP) were later added to the other in blender. Finally, the bacteriological agar (Alphatec, Barueri, SP) was dissolved in $200 \mathrm{~mL}$ of distilled water and brought to the fire, having been stirred constantly for a boil. The agar was then placed in blender along with other components and agitated for 2 min until homogenized. Before solidification, were distributed $100 \mathrm{~mL}$ of diet in plastic containers $(400 \mathrm{~mL})$ with perforated lids.

Using a pH meter (Phtek, model PHS 3B with Ruosull E-900 electrode) each diet was adjusted to the desired $\mathrm{pH}$ value by adding hydrochloric acid $(\mathrm{HCl}$, concentrated at $37 \%$ ) (Synth $\left.{ }^{\circledR}\right)$ in preliminary tests. The experiment was conducted in a completely randomized design with 7 treatments (diet $\mathrm{pH}$ ) and 10 replications (diet containers). The treatments contained diets with $\mathrm{pH} 6.0$ (without addition of $\mathrm{HCl}$ ), 5.0 (adding $3 \mathrm{~mL}$ of $\mathrm{HCl}$ ), 4.0 (adding $6 \mathrm{~mL}$ of $\mathrm{HCl}$ ), 3.0 (addition of $9 \mathrm{~mL}$ of $\mathrm{HCl}$ ), 2.0 (adding $12 \mathrm{~mL}$ of $\mathrm{HCl}$ ), 1.5 (adding $15 \mathrm{~mL}$ of $\mathrm{HCl}$ ) and 1.0 (addition of $18 \mathrm{~mL}$ of $\mathrm{HCl}$ ) (Table 1).

\subsection{Biological parameters}

After $24 \mathrm{~h}$ of the diet preparation, $0.1 \mathrm{~mL}$ of eggs of A. fraterculus ( $\sim 1.170$ eggs) and C. capitata ( 2.485 eggs), were inoculated separately, on filter paper, for larval development. The containers were packed in an air-conditioned room and near pupation, the $3^{\text {rd }}$ instar larvae were separated from the diet by rinsing under running water, using a sieve. Larvae were transfered to containers with moistened thin vermiculite and after $10 \mathrm{~d}$, the containers were inspected daily to separate the pupae, which were weighted with $24 \mathrm{~h}$ using a precision analytical scale (Shimadzu of Brazil, AUY 220 model) and packed in new containers until emergence.

Table 1. Components used to prepare the artificial diet for the larval development of Anastrepha fraterculus and Ceratitis capitata.

\begin{tabular}{|c|c|c|c|c|c|c|c|}
\hline \multirow{2}{*}{ Components $^{\mathrm{a}}$} & \multicolumn{7}{|c|}{ Diet pH } \\
\hline & 6.0 & 5.0 & 4.0 & 3.0 & 2.0 & 1.5 & 1.0 \\
\hline Refined sugar (g) & 60.0 & 60.0 & 60.0 & 60.0 & 60.0 & 60.0 & 60.0 \\
\hline Lyophilized brewer's yeast (g) & 60.0 & 60.0 & 60.0 & 60.0 & 60.0 & 60.0 & 60.0 \\
\hline Crude wheat germ (g) & 60.0 & 60.0 & 60.0 & 60.0 & 60.0 & 60.0 & 60.0 \\
\hline Water (distilled) (mL) & 800.0 & 800.0 & 800.0 & 800.0 & 800.0 & 800.0 & 800.0 \\
\hline Methylparahydroxybenzoate $(\mathrm{mL})$ & 8.0 & 8.0 & 8.0 & 8.0 & 8.0 & 8.0 & 8.0 \\
\hline Sodium benzoate $(\mathrm{g})$ & 1.0 & 1.0 & 1.0 & 1.0 & 1.0 & 1.0 & 1.0 \\
\hline Hydrochloric acid (mL) & 0.0 & 3.0 & 6.0 & 9.0 & 12.0 & 15.0 & 18.0 \\
\hline Bacteriological agar $(\mathrm{g})$ & 3.6 & 3.6 & 3.6 & 3.6 & 3.6 & 3.6 & 3.6 \\
\hline
\end{tabular}

${ }^{\mathrm{a} C}$ Components for $1 \mathrm{~L}$ of artificial diet (Salles, 1992; Nunes et al., 2013). 
We evaluated the duration and viability of larval and pupal stages, duration of egg stage and egg-adult period, number and weight of pupae and sex ratio. For each fruit fly species, 25 couples of each treatment were separated and packed in transparent plastic cups $(500 \mathrm{~mL}$, with 6-mm holes at the top), containing solid diet (sugar, wheat germ and yeast, at ratio $3: 1: 1$ ) and hydrophilic cotton soaked in distilled water, available in acrylic containers $(10 \mathrm{~mL})$. To determine fertility, artificial substrates were added to containers for oviposition, comprised of bacteriological agar $(14.0 \mathrm{~g})$, distilled water $(350 \mathrm{~mL})$, blackberry juice $(100 \mathrm{~mL})$ and methylparahydroxybenzoate Nipagin ${ }^{\mathrm{TM}}$ (4 mL), as described by Salles (1992). Daily observations were carried out, registering the number of eggs and mortality. Pre-oviposition and oviposition periods and longevity of males and females were calculated.

To evaluate fertility, 30 eggs of the second oviposition day of each female were removed from the artificial substrate using a surgical blade and a brush. Eggs were placed in Petri dishes on moist paper, with sponge cloth. The dishes were then wrapped with PVC film and kept in the growth chamber $\left(25 \pm 2{ }^{\circ} \mathrm{C}\right)$ until eggs were hatched and the number of larvae recorded.

\subsection{Data analysis}

Data were tested for normality by the Lilliefors test (Campos, 1983). In the event of normality, the data were submitted to the analysis of variance (ANOVA) and means compared using the Tukey test. When normality was not observed, the data were submitted to the Kruskal-Wallis analysis and the means compared using the Dunn test (Hollander and Wolf, 1973). For these analyses, the statistical software Bioestat 5.3 (Ayres et al., 2007) was used considering the probability of $5 \%$. Longevities of males and females were compared using the Log-rank test in the statistical software R and probability of 5\% (Ihaka and Gentleman, 1996).

\section{Results}

Diets with $\mathrm{pH}$ 6.0, 1.5 and 1.0. did not allow larval hatching for both fruit fly species. As for the duration of the egg stage of $A$. fraterculus, a significant difference was observed among treatments (Table 2). For the duration of the larval and pupal stages of $A$. fraterculus, no significant difference was observed (Table 2 ). However, smaller viability of the larval stage was observed when larvae were kept on diet with $\mathrm{pH} 2.0$, as well as lower viability of pupae, but differing from the diet with $\mathrm{pH}$ 3.0. A greater weight of the pupae of $A$. fraterculus was obtained on diet with $\mathrm{pH} 4.0$, as well as the largest number of pupae; however, this last parameter showed no difference composed to diet with pH 5.0 (Table 2).

The duration of the egg stage of $C$. capitata was similar to that of $A$. fraterculus, with longer period on diet with $\mathrm{pH} 2.0$, not differing from the diets with $\mathrm{pH} 3.0$ and 4.0 (Table 3). For the larval stage, the diets with pH 2.0 and 3.0 provided an increased development of $C$. capitata. A longer duration of the pupal stage of $C$. capitata was observed on diet with $\mathrm{pH} 4.0$, not differing from the diets with pH 5.0 and 2.0 (Table 3), as well as the longest egg-adult period, larger number of pupae and increased viability of larvae. The viability of pupae remained above $90 \%$ on diets with $\mathrm{pH}$ 5.0, 4.0 and 3.0.

A longer period of oviposition, fecundity and fertility for $A$. fraterculus was registered in females kept on a diet

Table 2. Biological parameters of immature stages of Anastrepha fraterculus kept on artificial diet with different $\mathrm{pH}$ values.

\begin{tabular}{|c|c|c|c|c|c|}
\hline \multirow{2}{*}{ Biological parameter } & \multicolumn{4}{|c|}{ Diet pH } & \multirow{2}{*}{$\begin{array}{l}\mathrm{CV} \\
(\%)\end{array}$} \\
\hline & $5.0[10]$ & $4.0[10]$ & $3.0[10]$ & $2.0[10]$ & \\
\hline Egg stage duration (days) ${ }^{b}$ & $\begin{array}{l}4.3 \pm 0.83 b \\
(3.0-6.0)\end{array}$ & $\begin{array}{l}5.1 \pm 0.66 b \\
(4.0-6.0)\end{array}$ & $\begin{array}{l}4.6 \pm 0.83 b \\
(4.0-7.0)\end{array}$ & $\begin{array}{l}6.6 \pm 1.01 \mathrm{a} \\
(5.0-9.0)\end{array}$ & 16.2 \\
\hline Larval stage duration (days) & $\begin{array}{l}7.9 \pm 1.28 \mathrm{~ns} \\
(6.0-10.0)\end{array}$ & $\begin{array}{l}8.1 \pm 1.52 \mathrm{~ns} \\
(7.0-11.0)\end{array}$ & $\begin{array}{l}8.6 \pm 2.59 \mathrm{~ns} \\
(6.0-11.0)\end{array}$ & $\begin{array}{l}6.5 \pm 2.01 \mathrm{~ns} \\
(4.0-10.0)\end{array}$ & 24.0 \\
\hline Pupal stage duration (days) & $\begin{array}{l}9.7 \pm 0.94 \mathrm{~ns} \\
(8.0-11.0)\end{array}$ & $\begin{array}{c}10.3 \pm 2.05 \mathrm{~ns} \\
(7.0-13.0)\end{array}$ & $\begin{array}{l}9.9 \pm 1.72 \mathrm{~ns} \\
(8.0-13.0)\end{array}$ & $\begin{array}{c}10.8 \pm 1.31 \mathrm{~ns} \\
(9.0-13.0)\end{array}$ & 14.8 \\
\hline Egg-adult period (days) ${ }^{b}$ & $\begin{array}{c}21.3 \pm 0.82 b \\
(20.0-23.0)\end{array}$ & $\begin{array}{c}23.5 \pm 1.77 \mathrm{a} \\
(22.0-26.0)\end{array}$ & $\begin{array}{l}22.9 \pm 1.28 \mathrm{ab} \\
(22.0-26.0)\end{array}$ & $\begin{array}{c}24.0 \pm 1.24 \mathrm{a} \\
(23.0-26.0)\end{array}$ & 5.5 \\
\hline Pupae weight (mg) ${ }^{\mathrm{c}}$ & $\begin{array}{c}12.7 \pm 0.49 b c \\
(12.10-13.90)\end{array}$ & $\begin{array}{c}15.7 \pm 1.02 \mathrm{a} \\
(14.40-17.70)\end{array}$ & $\begin{array}{c}13.5 \pm 0.56 b \\
(12.30-14.20)\end{array}$ & $\begin{array}{c}11.9 \pm 0.71 \mathrm{c} \\
(11.00-12.80)\end{array}$ & 5.1 \\
\hline Pupae number ${ }^{b}$ & $\begin{array}{c}19.6 \pm 3.33 \mathrm{ab} \\
(14.0-24.0)\end{array}$ & $\begin{array}{c}34.8 \pm 3.79 a \\
(30.0-39.0)\end{array}$ & $\begin{array}{c}17.8 \pm 2.04 b c \\
(15.0-21.0)\end{array}$ & $\begin{array}{l}8.2 \pm 1.93 \mathrm{c} \\
(5.0-11.0)\end{array}$ & 15.7 \\
\hline Larval viability $(\%)^{\mathrm{b}}$ & $\begin{array}{c}75.8 \pm 5.23 \mathrm{ab} \\
(68.00-84.00)\end{array}$ & $\begin{array}{c}83.0 \pm 4.50 \mathrm{a} \\
(78.26-91.18)\end{array}$ & $\begin{array}{c}81.9 \pm 5.30 \mathrm{a} \\
(74.07-88.24)\end{array}$ & $\begin{array}{c}65.8 \pm 3.66 b \\
(60.00-72.73)\end{array}$ & 6.0 \\
\hline Pupal viability (\%) & $\begin{array}{c}82.2 \pm 6.53 a \\
(70.83-90.48)\end{array}$ & $\begin{array}{c}86.9 \pm 6.46 a \\
(78.38-97.37)\end{array}$ & $\begin{array}{l}82.9 \pm 13.51 \mathrm{ab} \\
(61.11-100.0)\end{array}$ & $\begin{array}{c}65.8 \pm 20.10 b \\
(33.33-88.89)\end{array}$ & 15.6 \\
\hline
\end{tabular}

${ }^{a}$ Coefficient of variation. Means $\left( \pm\right.$ SE) followed by the same letter in the row do not differ using the ${ }^{\mathrm{b}}$ Dunn and ${ }^{\mathrm{c}}$ Tukey tests $(P<0.05)$, ns: not significant. Values in brackets indicate the number of repetitions and values in parentheses indicate the variation range. 
with pH 4.0 (Table 4). The sex ratio showed no significant difference between treatments. Females of $A$. fraterculus kept during the larval stage on artificial diet with $\mathrm{pH} 2.0$ presented the longest pre-oviposition period. Longer pre-oviposition of $C$. capitata were recorded in diets with $\mathrm{pH} 3.0$ and 5.0, being that the diet with $\mathrm{pH} 5.0$ did not differ from the other treatments (Table 5). The oviposition and fecundity period showed no significant difference between treatments. Greater fertility of $C$. capitata was recorded on diets with $\mathrm{pH} 5.0$ and 4.0; however, a higher sex ratio was found on diet with $\mathrm{pH}$ 2.0. For $A$. fraterculus the greater fertility was observed on diet with $\mathrm{pH}$ 4.0.

Regarding longevity of $A$. fraterculus, there was a significant difference for females $(P=0.0013)$ and males ( $P=0.0001)$ (Table 4). Adults of $A$. fraterculus, when kept on a diet with $\mathrm{pH} 4.0$, showed greater longevity. For females of $C$. capitata, there were no significant differences among treatments $(P=0.2748)$ (Table 5$)$. The males of this species showed greater longevity when kept during the immature phase on the diets with $\mathrm{pH} 3.0,4.0$ and $2.0(P=0.0046)$.

Table 3. Biological parameters of immature stages of Ceratitis capitata kept on artificial diet with different $\mathrm{pH}$ values.

\begin{tabular}{|c|c|c|c|c|c|}
\hline \multirow{2}{*}{ Biological parameter } & \multicolumn{4}{|c|}{ Diet pH } & \multirow{2}{*}{$\begin{array}{l}C^{a} \\
(\%)\end{array}$} \\
\hline & $5.0[10]$ & $4.0[10]$ & $3.0[10]$ & $2.0[10]$ & \\
\hline Egg stage duration (days) ${ }^{b}$ & $\begin{array}{l}4.8 \pm 0.99 b \\
(4.0-7.0)\end{array}$ & $\begin{array}{l}5.7 \pm 0.84 \mathrm{ab} \\
(4.0-7.0)\end{array}$ & $\begin{array}{l}6.1 \pm 0.70 \mathrm{a} \\
(5.0-8.0)\end{array}$ & $\begin{array}{l}6.5 \pm 0.85 a \\
(5.0-8.0)\end{array}$ & 14.9 \\
\hline Laval stage duration (days) $^{\mathrm{b}}$ & $\begin{array}{l}7.3 \pm 0.48 \mathrm{ab} \\
(7.0-8.0)\end{array}$ & $\begin{array}{l}7.7 \pm 0.82 \mathrm{a} \\
(7.0-9.0)\end{array}$ & $\begin{array}{l}5.4 \pm 0.84 c \\
(4.0-7.0)\end{array}$ & $\begin{array}{l}6.1 \pm 0.73 b c \\
(5.0-8.0)\end{array}$ & 11.2 \\
\hline Pupal stage duration (days) ${ }^{\mathrm{b}}$ & $\begin{array}{l}8.0 \pm 0.47 \mathrm{abc} \\
(7.0-9.0)\end{array}$ & $\begin{array}{l}9.1 \pm 0.87 \mathrm{a} \\
(8.0-11.0)\end{array}$ & $\begin{array}{l}7.2 \pm 0.91 \mathrm{c} \\
(6.0-8.0)\end{array}$ & $\begin{array}{l}8.2 \pm 0.63 \mathrm{abc} \\
(7.0-9.0)\end{array}$ & 8.9 \\
\hline Egg-adult period (days) ${ }^{b}$ & $\begin{array}{c}20.0 \pm 0.47 b \\
(19.0-21.0)\end{array}$ & $\begin{array}{c}22.1 \pm 0.87 \mathrm{a} \\
(21.0-24.0)\end{array}$ & $\begin{array}{c}19.2 \pm 0.91 b \\
(18.0-20.0)\end{array}$ & $\begin{array}{c}21.2 \pm 0.63 \mathrm{ab} \\
(20.0-22.2)\end{array}$ & 3.5 \\
\hline Pupae weight $(\mathrm{mg})^{\mathrm{b}}$ & $\begin{array}{c}13.3 \pm 0.48 \mathrm{a} \\
(12.30-13.90)\end{array}$ & $\begin{array}{l}12.9 \pm 0.32 \mathrm{ab} \\
(12.50-13.50)\end{array}$ & $\begin{array}{l}11.3 \pm 0.70 b \\
(10.30-13.0)\end{array}$ & $\begin{array}{l}10.0 \pm 0.41 b \\
(9.20-10.80)\end{array}$ & 4.1 \\
\hline Pupae number ${ }^{\mathrm{c}}$ & $\begin{array}{c}52.0 \pm 7.40 b \\
(44.0-67.0)\end{array}$ & $\begin{array}{c}63.8 \pm 6.10 \mathrm{a} \\
(55.0-74.0)\end{array}$ & $\begin{array}{c}40.3 \pm 6.66 \mathrm{c} \\
(33.0-53.0)\end{array}$ & $\begin{array}{c}37.6 \pm 7.38 \mathrm{c} \\
(26.0-51.0)\end{array}$ & 15.0 \\
\hline Larval viability $(\%)^{\mathrm{c}}$ & $\begin{array}{c}82.1 \pm 8.33 b \\
(70.97-97.10)\end{array}$ & $\begin{array}{l}93.8 \pm 2.78 \mathrm{a} \\
(87.30-97.37)\end{array}$ & $\begin{array}{l}64.1 \pm 10.02 c \\
(53.23-81.97)\end{array}$ & $\begin{array}{l}62.3 \pm 12.32 d \\
(40.63-78.46)\end{array}$ & 12.1 \\
\hline Pupal viability $(\%)^{\mathrm{b}}$ & $\begin{array}{c}91.5 \pm 5.99 a \\
(82.00-97.73)\end{array}$ & $\begin{array}{c}98.7 \pm 1.77 \mathrm{a} \\
(95.16-100.00)\end{array}$ & $\begin{array}{c}91.4 \pm 2.19 \mathrm{ab} \\
(87.88-94.12)\end{array}$ & $\begin{array}{c}78.8 \pm 5.84 b \\
(66.67-85.71)\end{array}$ & 4.5 \\
\hline
\end{tabular}

${ }^{\mathrm{a}}$ Coefficient of variation. Means $( \pm \mathrm{SE})$ followed by the same letter in the row do not differ using the ${ }^{\mathrm{b}}$ Dunn and ${ }^{\mathrm{c}}$ Tukey tests $(P<0.05)$. Values in brackets indicate the number of repetitions and values in parentheses indicate the variation range.

Table 4. Biological parameters of adults of Anastrepha fraterculus kept during the larval stage on artificial diet with different $\mathrm{pH}$ values.

\begin{tabular}{|c|c|c|c|c|c|}
\hline \multirow{2}{*}{ Biological parameter } & \multicolumn{4}{|c|}{ Diet pH } & \multirow{2}{*}{$\begin{array}{l}\mathrm{CV}^{\mathrm{a}} \\
(\%)\end{array}$} \\
\hline & $5.0[23]$ & $4.0[25]$ & $3.0[18]$ & $2.0[21]$ & \\
\hline Pre-oviposition period (days) ${ }^{\mathrm{b}}$ & $\begin{array}{l}13.9 \pm 1.08 b \\
(13.0-16.0)\end{array}$ & $\begin{array}{l}12.7 \pm 1.64 \mathrm{c} \\
(12.0-20.0)\end{array}$ & $\begin{array}{l}16.2 \pm 6.93 b c \\
(12.0-32.0)\end{array}$ & $\begin{array}{l}16.9 \pm 3.72 \mathrm{a} \\
(15.0-31.0)\end{array}$ & 21.3 \\
\hline Oviposition period (days) ${ }^{\mathrm{b}}$ & $\begin{array}{l}14.6 \pm 10.83 b \\
(1.0-41.0)\end{array}$ & $\begin{array}{l}26.8 \pm 11.45 a \\
(4.0-44.0)\end{array}$ & $\begin{array}{l}12.0 \pm 12.60 \mathrm{~b} \\
(1.0-51.0)\end{array}$ & $\begin{array}{l}14.5 \pm 10.93 b \\
(2.0-34.0)\end{array}$ & 7.4 \\
\hline Fecundity ${ }^{\mathrm{b}}$ & $\begin{array}{l}416.7 \pm 31.02 b \\
(20.0-991.0)\end{array}$ & $\begin{array}{c}1302.8 \pm 60.82 \mathrm{a} \\
(134.0-2181.0)\end{array}$ & $\begin{array}{l}322.8 \pm 36.33 b \\
(35.0-1323.0)\end{array}$ & $\begin{array}{c}313.6 \pm 26.47 b \\
(53.0-820.0)\end{array}$ & 7.9 \\
\hline Fertility $(\%)^{\mathrm{b}}$ & $\begin{array}{r}61.2 \pm 5.68 b \\
(43.33-68.00)\end{array}$ & $\begin{array}{r}73.1 \pm 2.64 a \\
(70.00-76.67)\end{array}$ & $\begin{array}{r}60.9 \pm 4.13 b \\
(53.33-66.67)\end{array}$ & $\begin{array}{l}57.7 \pm 7.02 b \\
(43.3-66.67)\end{array}$ & 7.9 \\
\hline Sex ratio ${ }^{b}$ & $\begin{array}{l}0.4 \pm 0.06 \mathrm{~ns} \\
(0.40-0.61)\end{array}$ & $\begin{array}{l}0.5 \pm 0.01 \mathrm{~ns} \\
(0.46-0.52)\end{array}$ & $\begin{array}{l}0.4 \pm 0.09 \mathrm{~ns} \\
(0.36-0.63)\end{array}$ & $\begin{array}{l}0.4 \pm 0.18 \mathrm{~ns} \\
(0.20-0.71)\end{array}$ & 19.1 \\
\hline Survival (females) (days) ${ }^{c}$ & $\begin{array}{l}31.2 \pm 16.01 b \\
(13.0-83.0)\end{array}$ & $\begin{array}{l}52.8 \pm 22.66 \mathrm{a} \\
(17.0-96.0)\end{array}$ & $\begin{array}{l}34.0 \pm 17.72 b \\
(11.0-80.0)\end{array}$ & $\begin{array}{l}31.4 \pm 14.12 b \\
(8.0-60.0)\end{array}$ & 0.5 \\
\hline Survival (males) (days) ${ }^{\mathrm{c}}$ & $\begin{array}{l}42.6 \pm 25.71 b \\
(16.0-119.0)\end{array}$ & $\begin{array}{l}80.4 \pm 31.20 \mathrm{a} \\
(19.0-126.0)\end{array}$ & $\begin{array}{l}37.2 \pm 15.52 b \\
(11.0-72.0)\end{array}$ & $\begin{array}{l}30.2 \pm 17.30 b \\
(10.0-80.0)\end{array}$ & 0.6 \\
\hline
\end{tabular}

${ }^{\mathrm{a}}$ Coefficient of variation. Means $( \pm \mathrm{SE})$ followed by the same letter in the row do not differ using the ${ }^{b} \mathrm{Dunn}$ and ${ }^{\mathrm{c}}$ Log-rank tests $(P<0.05)$, ns: not significant. Values in brackets indicate the number of repetitions (couples) used in the study on the biology of adults of Anastrepha fraterculus and values in parentheses indicate the variation range. 
Table 5. Biological parameters of adults of Ceratitis capitata kept during the larval stage on artificial diet with different $\mathrm{pH}$ values.

\begin{tabular}{|c|c|c|c|c|c|}
\hline \multirow{2}{*}{ Biological parameter } & \multicolumn{4}{|c|}{ Diet pH } & \multirow{2}{*}{$\begin{array}{l}C V^{a} \\
(\%)\end{array}$} \\
\hline & $5.0[18]$ & $4.0[25]$ & $3.0[25]$ & $2.0[19]$ & \\
\hline Pre-oviposition period (days) ${ }^{b}$ & $\begin{array}{c}12.2 \pm 2.57 \mathrm{ab} \\
(10.0-21.0)\end{array}$ & $\begin{array}{r}11.1 \pm 1.43 b \\
(10.0-14.0)\end{array}$ & $\begin{array}{r}15.7 \pm 6.16 \mathrm{a} \\
(10.0-35.0)\end{array}$ & $\begin{array}{c}13.7 \pm 8.01 b \\
(9.0-38.0)\end{array}$ & 32.8 \\
\hline Oviposition period (days) ${ }^{\mathrm{b}}$ & $\begin{array}{l}11.9 \pm 10.89 \mathrm{~ns} \\
(1.0-33.0)\end{array}$ & $\begin{array}{c}17.7 \pm 9.78 \mathrm{~ns} \\
(1.0-32.0)\end{array}$ & $\begin{array}{c}15.2 \pm 11.36 \mathrm{~ns} \\
(1.0-36.0)\end{array}$ & $\begin{array}{c}13.0 \pm 13.37 \mathrm{~ns} \\
(1.0-45.0)\end{array}$ & 81.0 \\
\hline Fecundity $^{\mathrm{b}}$ & $\begin{array}{c}304.0 \pm 29.23 \mathrm{~ns} \\
\quad(9.0-1109.0)\end{array}$ & $\begin{array}{c}429.0 \pm 23.65 \mathrm{~ns} \\
\quad(13.0-921.0)\end{array}$ & $\begin{array}{c}311.4 \pm 29.42 \mathrm{~ns} \\
(3.0-1067.0)\end{array}$ & $\begin{array}{c}257.2 \pm 28.22 \mathrm{~ns} \\
\quad(10.0-910.0)\end{array}$ & 89.4 \\
\hline Fertility $(\%)^{\mathrm{b}}$ & $\begin{array}{l}73.3 \pm 6.16 a \\
(63.33-86.67)\end{array}$ & $\begin{array}{l}79.4 \pm 4.55 a \\
(70.00-86.67)\end{array}$ & $\begin{array}{r}64.5 \pm 9.99 b \\
(50.0-95.0)\end{array}$ & $\begin{array}{r}62.8 \pm 7.04 b \\
(50.0-73.33)\end{array}$ & 10.2 \\
\hline Sex ratio ${ }^{b}$ & $\begin{array}{l}0.5 \pm 0.03 \mathrm{ab} \\
(0.48-0.60)\end{array}$ & $\begin{array}{l}0.5 \pm 0.01 b \\
(0.50-0.51)\end{array}$ & $\begin{array}{l}0.5 \pm 0.04 \mathrm{ab} \\
(0.50-0.65)\end{array}$ & $\begin{array}{l}0.5 \pm 0.07 a \\
(0.42-0.65)\end{array}$ & 7.3 \\
\hline Survival (females) (days) ${ }^{c}$ & $\begin{array}{c}33.8 \pm 24.06 \mathrm{a} \\
(13.0-91.0)\end{array}$ & $\begin{array}{c}47.1 \pm 21.08 \mathrm{a} \\
(22.0-93.0)\end{array}$ & $\begin{array}{c}46.6 \pm 23.49 a \\
(22.0-125.0)\end{array}$ & $\begin{array}{c}44.0 \pm 27.99 \mathrm{a} \\
(8.0-101.0)\end{array}$ & 0.4 \\
\hline Survival (males) (days) ${ }^{\mathrm{c}}$ & $\begin{array}{c}25.0 \pm 25.89 b \\
(14.0-93.0)\end{array}$ & $\begin{array}{c}46.3 \pm 15.98 b \\
(22.0-85.0)\end{array}$ & $\begin{array}{c}43.6 \pm 21.20 \mathrm{~b} \\
(19.0-112.0)\end{array}$ & $\begin{array}{c}41.0 \pm 31.31 \mathrm{a} \\
(8.0-115.0)\end{array}$ & 0.5 \\
\hline
\end{tabular}

${ }^{a}$ Coefficient of variation. Means $\left( \pm\right.$ SE) followed by the same letter in the row do not differ using the ${ }^{b}$ Dunn and ${ }^{c}$ Log-rank tests $(P<0.05)$, ns: not significant. Values in brackets indicate the number of repetitions (couples) used in the study on the biology of adults of Ceratitis capitata and values in parentheses indicate the variation range.

\section{Discussion}

On diet with $\mathrm{pH} 6.0$, no larval hatching occurred for both species tested, possibly due to the rapid microbiological contamination of the diet. Vargas et al. (1984), found rapid deterioration in artificial diets with $\mathrm{pH}$ between 5.0 and 6.0. Vera et al. (2014) found contamination on diets for larval development with $\mathrm{pH}$ 4.5. On diets with $\mathrm{pH} 1.5$ and 1.0, there was no contamination and no larval hatching either, which may be related to the infertility of eggs on the acid medium (Von Zuben, 1998).

For A. fraterculus, when the insects were kept on the diet with $\mathrm{pH}$ 2.0, delayed egg hatching occurred, causing longer egg-adult period. In general, immature forms of holometabolous insects complete their development in acidic medium, but in a longer period compared to those on alkaline or neutral media (Gullan and Cranston, 2012).

For both species of fruit fly, the smaller viability of the larval and pupae stage observed when larvae were kept on diet with $\mathrm{pH} 2.0$, but differing from the diet with $\mathrm{pH} 3.0$, is similar to results reported for Bactrocera invadens Drew, Tsuruta \& White, 2005 (Diptera: Tephritidae) using liquid diet with pH 3.5 Ekesi et al. (2014). Vera et al. (2014) evaluated diets for $A$. fraterculus with addition of ascorbic, citric and lactic acid and found that, irrespective of the acid used, the $\mathrm{pH}$ of 3.5 appears to be too low for egg hatch, larval viability, egg-to-pupa recovery, and pupal weight.

In the digestion process, the larvae of Tephritidae act in association with endosymbionts, which inhabit the intestinal lumen (Prokopy et al., 1993). These microorganisms present a mutualistic relationship essential for the proper growth and development of its host, ensuring its reproductive success (Dossi and Cônsoli, 2010). For fruit flies, Enterobacter agglomerans and Klebsiella pneumoniae are the main bacteria associated with the digestive tract (Lauzon et al., 1998; 2009). According to Engel and Moran (2013), composition and metabolic capacity of intestinal microbiota depend on the conditions of the intestinal lumen of the insect, which may present extreme $\mathrm{pH}$ variations, once it is actively regulated according to the food ingested.

In relation to weight of the pupae of $A$. fraterculus, Nunes et al. (2013) found similar values (15.3 mg) using the same artificial diet with $\mathrm{pH}$ 4.0. The greater weight and larger number of pupae may be related to a favorable condition for larval development at this $\mathrm{pH}$ level, as well as for the bacteria associated to its intestinal flora. For the larval stage, diets with $\mathrm{pH} 2.0$ and 3.0 provided an increased development of $C$. capitata. Papachristos et al. (2008) found that the longest period of larval development of C. capitata was found in lemon fruit (C. limon) and sour orange (C. aurantium), with $\mathrm{pH}$ values of 2.3 and 2.7 , respectively.

The viability of pupae remained above $90 \%$ on diets with pH 5.0, 4.0 and 3.0, corroborating Chan Junior and Jang (1995). Vargas et al. (1984) also found lower pupae weight $(7.8 \mathrm{mg})$ and viability of pupae $(34.4 \%)$ of C. capitata on artificial diet with $\mathrm{pH}$ below 4.0 , similar to the results obtained in this study.

Artificial diet with $\mathrm{pH} 2.0$ caused the longest pre-oviposition period for $A$. fraterculus. In insects, egg production involves the synthesis of specific lipo-glycoproteins of females (vitelogenins), followed by their passage to the oocytes (Gullan and Cranston, 2012). DiMario and Mahowald (1986) found that ovarian tissue (follicular cells and oocytes) of Drosophila melanogaster Meigen, 1830 (Diptera: Drosophilidae) kept in vitro presented low capacity of endocytosis of vitellogenin in environments with $\mathrm{pH}$ lower than 6.6. This fact could explain the longer 
pre-oviposition period of $A$. fraterculus, given that the vitellogenesis process is critical for egg formation (Gullan and Cranston, 2012).

Greater fertility of $C$. capitata was recorded on diets with $\mathrm{pH} 5.0$ and 4.0; and higher female sex ratio was found on diet with $\mathrm{pH}$ 2.0. This suggests that the diet with very acidic $\mathrm{pH}$ provided the largest number of females of C. capitata, although with low fertility. Vera et al. (2014) found similar results for $A$. fraterculus, with reduction in egg viability with decreasing diet $\mathrm{pH}$. The diet with $\mathrm{pH}$ 3.5 resulted in lower egg hatch, corroborating out results. Regarding longevity, males of C. capitata showed greater longevity when kept during the immature phase on the diets with $\mathrm{pH} 3.0,4.0$ and 2.0. As a generalist species, C. capitata keeps genetic variation to allow expression of adaptive plasticity in a variety of environments compared to $A$. fraterculus (Forister et al., 2012).

In conclusions, artificial diets with $\mathrm{pH}$ below 2.0 do not provide suitable conditions for larval hatching of A. fraterculus and C. capitata. Diets with $\mathrm{pH}$ below 4.0 affect the development of $A$. fraterculus, promoting lower viability of larvae and delayed duration of the egg stage, egg-adult and pre-oviposition period. Diets with $\mathrm{pH} 4.0$ and 5.0 provide greater fertility, weight and number of pupae of both fruit fly species and greater fecundity, oviposition period and longevity of males and females of $A$. fraterculus.

\section{Acknowledgements}

The authors wish to thank National Council for Scientific and Technological Development (CNPq) for the scholarship granted to the first author.

\section{References}

AYRES, M., AYRES JÚNIOR, M., AYRES, D.L. and SANTOS, A.A.S., 2007. BioeEstat: aplicações estatísticas nas áreas das Ciências Bio-médicas. Belém: ONG Mamirauá.

CAMPOS, H., 1983. Estatística experimental não-paramétrica. 2nd ed. Piracicaba: ESALQ. 349 p.

CHAN JUNIOR, H.T. and JANG, E.B., 1995. Diet pH effects on mass rearing of Mediterranean fruit fly (Diptera: Tephritidae). Journal of Economic Entomology, vol. 88, no. 3, pp. 569-573. http://dx.doi.org/10.1093/jee/88.3.569.

CHAPMAN, R.F., 2013. The insects: structure and function. 5th ed. New York: Cambridge University Press. 959 p.

CLADERA, J.L., VILARDI, J.C., JURI, M., PAULIN, L.E., GIARDINI, M.C., GÓMEZ CENDRA, P.V., SEGURA, D.F. and LANZA VECCHIA, S.B., 2014. Genetics and biology of Anastrepha fraterculus: research supporting the use of the sterile insect technique (SIT) to control this pest in Argentina. BMC Genetics, vol. 15, no. 2, suppl. 2, pp. 1-14. PMid:25471175.

COHEN, A.C., 2004. Insect diets: science and technology. 2nd ed. Boca Raton: CRC Press. 324 p.

DIMARIO, P.J. and MAHOWALD, A.P., 1986. The effects of $\mathrm{pH}$ and weak bases on the in vitro endocytosis of vitellogenin by oocytes of Drosophila melanogaster. Cell and Tissue Research, vol. 246, no. 1, pp. 103-108. http://dx.doi.org/10.1007/BF00219005. PMid:3096571.

DOSSI, F.C.A. and CÔNSOLI, F.L., 2010. Desenvolvimento ovariano e influência da cópula na maturação dos ovários de Diaphorina citri Kuwayama (Hemiptera: Psyllidae). Neotropical Entomology, vol. 39, no. 3, pp. 414-419. http://dx.doi.org/10.1590/ S1519-566X2010000300015. PMid:20676515.

EKESI, S., MOHAMED, S.A. and CHANG, C.L., 2014. A liquid larval diet for rearing Bactrocera invadens and Ceratitis fasciventris (Diptera: Tephritidae). International Journal of Tropical Insect Science, vol. 34, no. S1, pp. S90-S98. http:// dx.doi.org/10.1017/S1742758414000113.

ENGEL, P. and MORAN, N.A., 2013. The gut microbiota of insects: diversity in structure and function. FEMS Microbiology Reviews, vol. 37, no. 5, pp. 699-735. http://dx.doi.org/10.1111/15746976.12025. PMid:23692388

FORISTER, M.L., DYER, L.A., SINGER, M.S., STIREMAN III, J.O. and LILL, J.T., 2012. Revisiting the evolution of ecological specialization, with emphasis on insect plant interactions. Ecology, vol. 93, no. 5, pp. 981-991. http://dx.doi.org/10.1890/11-0650.1. PMid:22764485.

GONÇALVES, R.S., NAVA, D.E., PEREIRA, H.C., LISBÔA, H., GRÜTZMACHER, A.D. and VALGAS, R.A., 2013. Biology and fertility life table of Aganaspis pelleranoi (Hymenoptera: Figitidae) in larvae of Anastrepha fraterculus and Ceratitis capitata (Diptera: Tephritidae). Annals of the Entomological Society of America, vol. 106, no. 6, pp. 791-798. http://dx.doi. org/10.1603/AN13044.

GULLAN, P.J. and CRANSTON, P.S., 2012. Os insetos: um resumo de entomologia. 4th ed. São Paulo: Roca. 496 p.

HARRISON, J.F., 2001. Insect acid-base physiology. Annual Review of Entomology, vol. 46, no. 1, pp. 221-250. http://dx.doi. org/10.1146/annurev.ento.46.1.221. PMid:11112169.

HOLLANDER, M. and WOLF, D.A., 1973. Nonparametric statistical methods. New York: John Wiley \& Sons. 503 p.

HU, X.P., PROKOPY, R. and AVERILL, A., 1999. Effects of $\mathrm{pH}$ on feeding responses in the apple maggot fly, Rhagoletis pomonella (Diptera: Tephritidae). Journal of Insect Physiology, vol. 45 , no. 2 , pp. 151-157. http://dx.doi.org/10.1016/S00221910(98)00109-7. PMid:12770383.

IHAKA, R. and GENTLEMAN, R., 1996. R: a language for data analysis and graphics. Journal of Computational and Graphical Statistics, vol. 5, no. 3, pp. 299-314.

KOVAL, T.M. and SUPPES, D.L., 1990.pH dependency of cell attachment and growth at both clonal and subculture densities of cultured lepidopteran cells. In Vitro Cellular \& Developmental Biology, vol. 26, no. 7, pp. 665-670. http://dx.doi.org/10.1007/ BF02624422. PMid:2384444

LAUZON, C.R., MCCOMBS, S.D., POTTER, S.E. and PEABODY, N.C., 2009. Establishment and vertical passage of Enterobacter (Pantoea) agglomerans and Klebsiella pneumoniae through all life stages of the Mediterranean fruit fly (Diptera: Tephritidae). Annals of the Entomological Society of America, vol. 102, no. 1, pp. 85-95. http://dx.doi.org/10.1603/008.102.0109.

LAUZON, C.R., SJOGREN, R.E., WRIGHT, S.E. and PROKOPY, R.J., 1998. Attraction of Rhagoletis pomonella (Diptera: Tephritidae) flies to odor of bacteria: apparent confinement to specialized 
members of Enterobacteriaceae. Environmental Entomology, vol. 27, no. 4, pp. 853-857. http://dx.doi.org/10.1093/ee/27.4.853.

NESTEL, D., PAPADOPOULOS, N.T., PASCACIO-VILLAFÁN, C., RIGHINI, N., ALTÚZAR-MOLINA, A.R. and ALUJA, M., 2016. Resource allocation and compensation during development in holometabolous insects. Journal of Insect Physiology, vol. 95, pp. 78-88. http://dx.doi.org/10.1016/j.jinsphys.2016.09.010. PMid:27650504.

NUNES, A.M., COSTA, K.Z., FAGGIONI, K.M., COSTA, M., GONÇALVES, R.S., WALDER, J.M.M., GARCIA, M.S. and NAVA, D.E., 2013. Dietas artificiais para a criação de larvas e adultos da mosca-das-frutas sul-americana. Pesquisa Agropecuária Brasileira, vol. 48, no. 10, pp. 1309-1314. http:// dx.doi.org/10.1590/S0100-204X2013001000001.

OLIVEIRA, F.Q., BOIÇA JUNIOR, A.L., COSTA, M.L.Z., SANCHES, P.A., WALDER, J.M.M. and BATISTA, J.L., 2014. Preference and infestation level of Anastrepha fraterculus (Wiedemann, 1830) on fruits of some Psidium guajava L. cultivars and relation to their physicochemical parameters. Phytoparasitica, vol. 42, no. 4, pp. 475-483. http://dx.doi.org/10.1007/s12600014-0384-7.

PAPACHRISTOS, D.M., PAPADOPOULOS, N.T. and NANOS, G.D., 2008. Survival and development of immature stages of the Mediterranean fruit fly (Diptera: Tephritidae) in citrus fruit. Journal of Economic Entomology, vol. 101, no. 3, pp. 866-872. http://dx.doi.org/10.1093/jee/101.3.866. PMid:18613588.

PAPACHRISTOS, D.P. and PAPADOPOULOS, N.K., 2009. Are citrus species favorable hosts for the Mediterranean fruit fly? A demographic perspective. Entomologia Experimentalis et Applicata, vol. 132, no. 1, pp. 1-12. http://dx.doi.org/10.1111/j.15707458.2009.00861.x.

PARRA, J.R.P., 2009. A evolução das dietas artificiais e suas interações em ciência e tecnologia. In: A.R. PANIZZI and J.R.P. PARRA, eds. Bioecologia e nutrição de insetos: base para o manejo integrado de pragas. Brasília: Embrapa Recursos Genéticos e Biotecnologia, pp. 91-174.

PROKOPY, R.J., COOLEY, S.S., GALARZA, L., BERGWEILER, C. and LAUZON, C.R., 1993. Bird droppings as natural food compete with bait sprays against Rhagoletis pomonella flies
(Diptera: Tephritidae). Canadian Entomologist, vol. 125, no. 3, pp. 413-422. http://dx.doi.org/10.4039/Ent125413-3.

RUIZ, M.J., JUÁREZ, M.L., ALZOGARAY, R.A., ARRIGHI, F., ARROYO, L., GASTAMINZA, G., WILLINK, E., BARDÓN, A.V. and VERA, T., 2014. Toxic effect of citrus peel constituents on Anastrepha fraterculus Wiedemann and Ceratitis capitata Wiedemann immature stages. Journal of Agricultural and Food Chemistry, vol. 62, no. 41, pp. 10084-10091. http://dx.doi. org/10.1021/jf503063b. PMid:25237738.

SALLES, L.A.B., 1992. Metodologia de criação de Anastrepha fraterculus (Wiedemann, 1830) (Diptera: Tephritidae) em dieta artificial em laboratório. Annals of the Entomological Society of Brazil, vol. 21, pp. 479-486.

VARGAS, R.I., WILLIAMSON, D.L., CHANG, H. and KOMURA, M., 1984. Effects of larval-diet $\mathrm{pH}$ on worker comfort and insect quality during mass production of Mediterranean fruit fly (Diptera: Tephritidae) in Hawaii. Journal of Environmental Sciences, vol. 19, no. 5, pp. 621-630. http://dx.doi.org/10.1080/10934528409375181.

VERA, M.T., OVIEDO, A., ABRAHAM, S., RUIZ, J., MENDOZA, M., CHANG, C.L. and WILLINK, E., 2014. Development of a larval diet for the South American fruit fly Anastrepha fraterculus (Diptera: Tephritidae). International Journal of Tropical Insect Science, vol. 34, no. S1, pp. S73-S81. http://dx.doi.org/10.1017/ S1742758414000150.

VON ZUBEN, C.J., 1998. Comportamento de oviposturas individuais, percentagem de eclosão e peso larval mínimo para pupação em populações de Chrysomya megacephala (F.). Annals of the Entomological Society of Brazil, vol. 27, no. 4, pp. 525-533. http://dx.doi.org/10.1590/S0301-80591998000400004.

ZUCCHI, R.A., 2008 [viewed 15 October 2016]. Fruit flies in Brazil: Anastrepha species their host plants and parasitoids [online]. Piracicaba. Available from: http://www.lea.esalq.usp. br/anastrepha/

ZUCCHI, R.A., 2012 [viewed 20 October 2016]. Fruit flies in Brazil: hosts and parasitoids of the Mediterranean fruit fly [online]. Piracicaba. Available from: http://www.lea.esalq.usp.br/ceratitis/ 